\title{
Analysis of factors predisposing to the occurrence of psoriasis among patients qualified for cyclosporine A therapy - a pilot study
}

\author{
Analiza czynników predysponujących do wystąpienia objawów łuszczycy wśród \\ pacjentów zakwalifikowanych do terapii cyklosporyną $A$ - badania wstępne
}

\author{
Beniamin O. Grabarek', Anna Michalska-Bańkowska², Dominika L. Wcisło-Dziadecka
}

\begin{abstract}
'Department of Molecular Biology, Chair of Molecular Biology, Faculty of Pharmacy with the Department of Laboratory Medicine in Sosnowiec, Medical University of Silesia in Katowice, Poland

2Department of Dermatology, School of Medicine in Katowice, Medical University of Silesia, Katowice, Poland

${ }^{3}$ Department of Cosmetology, School of Pharmacy with the Division of Laboratory Medicine in Sosnowiec, Medical University of Silesia, Katowice, Poland

'Zakład Biologii Molekularnej Katedry Biologii Molekularnej, Wydział Farmaceutyczny z Oddziałem Medycyny Laboratoryjnej w Sosnowcu, Sląski Uniwersytet Medyczny w Katowicach, Polska

'Zakład Biologii Molekularnej Katedry Biologii Molekularnej, Wydział Farmaceutyczny z Oddziałem Medycyny Laboratoryjnej w Sosnowcu, Śląski Uniwersytet Medyczny w Katowicach, Polska

${ }^{3}$ Katedra Kosmetologii, Wydział Farmaceutyczny z Oddziałem Medycyny Laboratoryjnej w Sosnowcu, Śląski Uniwersytet Medyczny w Katowicach, Polska
\end{abstract}

Psoriasis is an autoimmune disease of inflammatory as well as chronic nature, and periods of symptom exacerbation [1].

This paper analyses factors predisposing individuals to develop psoriasis: data mentioned in table 1 were collected from 32 patients ( 20 men $-63 \%$, and 12 women - $37 \%$ ) with diagnosed moderate to severe plaque psoriasis (psoriasis vulgaris) classified to be treated with cyclosporine A during their first appointments.

All individuals participating in the study provided their informed voluntary written consent for participation and associated procedures. The study was conducted pursuant to the consent of Bioethical Committee of the Medical University of Silesia in Katowice, Poland - Resolution No. KNW/0022/ KB1/59/I/13/14 as of 27 $7^{\text {th }}$ May 2014.

Psoriasis should cease to be perceived as a skin disease only, and its diagnostics as well as treatment should not be limited to dermatology. It needs to be remembered that the majority of patients seek support at their GP's and/or paediatrician's in the first place. Thus, these physicians constitute the first and most important link between the patient and further specialist treatment. The analysis shows that men and women as well as youths and adults suffer from the disease, what is another premise for GPs to broaden their knowledge with regard to psoriasis.
Łuszczyca to przewlekła choroba autoimmunologiczna o charakterze zapalnym, która przebiega z okresami zaostrzeń [1].

W niniejszej pracy przeanalizowano czynniki predysponujące do wystąpienia łuszczycy u 32 pacjentów ze zdiagnozowaną łuszczycą zwykłą (20 mężczyzn $63 \%$, i 12 kobiet - 37\%) o nasileniu umiarkowanym do ciężkiego, zakwalifikowanych do leczenia cyklosporyną $A$, od których zebrano dane podczas pierwszej wizyty (tab. 1).

Wszyscy uczestnicy wyrazili świadomą, dobrowolną, pisemną zgodę na udział w badaniu oraz związane z nim procedury. Badanie przeprowadzono za zgodą Komisji Bioetycznej Śląskiego Uniwersytetu Medycznego w Katowicach - Uchwała nr KNW/0022/ KB1/59/I/13/14 z dnia 27 maja 2014 roku.

Łuszczycę należy przestać postrzegać jako chorobę tylko skóry, której diagnostyka i leczenie ograniczone są wyłącznie do dermatologii. Trzeba pamiętać, że większość pacjentów najpierw szuka pomocy u lekarza rodzinnego i/lub pediatry. Stanowią oni pierwsze, najważniejsze ogniwo pomiędzy pacjentem a dalszym leczeniem specjalistycznym. Analiza pokazuje, że chorują zarówno mężczyźni, jak i kobiety, młodzież oraz osoby dorosłe, co stanowi kolejną przesłankę dla lekarzy pierwszego kontaktu do pogłębiania wiedzy na temat łuszczycy. 
Table I. Characteristics of patients with psoriasis qualified for cyclosporin A therapy

Tabela I. Charakterystyka pacjentów z łuszczycą zakwalifikowanych do terapii cyklosporyną A

\begin{tabular}{|c|c|c|}
\hline \multicolumn{2}{|l|}{ Parameter/Parametr } & $\begin{array}{c}N \text { or mean } \pm \\
\text { standard deviation/ } \\
N \text { lub średnia } \pm \\
\text { odchylenie standardowe }\end{array}$ \\
\hline \multicolumn{2}{|l|}{ Age [years] Wiek [lata] } & $53.9 \pm 10.4$ \\
\hline \multicolumn{2}{|c|}{ Disease onset [years]/Początek choroby [lata] } & $34 \pm 14.8$ \\
\hline \multirow[t]{2}{*}{ Sex/Płeć } & Man/Mężczyzna & 20 \\
\hline & Woman/Kobieta & 12 \\
\hline \multirow{3}{*}{$\begin{array}{l}\text { Causing factors/Czynniki } \\
\text { wywołujące }\end{array}$} & Stress, infections/Stres, infekcje & 29 \\
\hline & Mechanical injuries, surgeries/Urazy mechaniczne, operacje & 3 \\
\hline & Drugs - lithium, $\beta$-blockers/Leki - lit, $\beta$-adrenolityki & 0 \\
\hline \multirow{5}{*}{$\begin{array}{l}\text { Familial clustering/ } \\
\text { Rodzinne występowanie }\end{array}$} & Parents/Rodzice & 6 \\
\hline & Siblings/Rodzeństwo & I \\
\hline & Grandparents/Dziadkowie & I \\
\hline & Distant family/Dalsza rodzina & 2 \\
\hline & N/A/Bez związku & 22 \\
\hline \multirow{3}{*}{$\begin{array}{l}\text { Professional activity/ } \\
\text { Aktywność zawodowa }\end{array}$} & White-collar worker/Pracownik umysłowy & 7 \\
\hline & Blue-collar worker/Pracownik fizyczny & 11 \\
\hline & Pensioner, annuitant, unemployed/Emeryt, rencista, bezrobotny & 14 \\
\hline \multirow[t]{3}{*}{ Stimulants/Używki } & Alcohol/Alkohol & 15 \\
\hline & Cigarettes/Papierosy & 6 \\
\hline & Drugs/Narkotyki & 0 \\
\hline
\end{tabular}

Having compared factors causing psoriasis in the studied group (table 1), is may be concluded that stress and infections have the greatest influence on the incidence of psoriasis - 29 (91\%) individuals, whereas mechanical injuries and surgeries are of lesser significance $-3(9 \%)$ individuals.

Bacterial and viral superantigens may influence the mechanism of T-lymphocyte migration from capillary vessels to the epidermis as a result of stimulation skin lymphocyte receptors, what results in an induction of inflammation. Onset of psoriasis is often caused by an infection with various microorganisms, primarily streptococci and staphylococci $[2,3]$. Hence, it appears that patients with numerous recurrent infections should be especially taken care of as they are at a higher risk to develop psoriasis. Children and teenagers in whom frequent bacterial infections or superinfections are observed constitute a group that is especially prone to infections. Streptococcal pharyngitis is a typical disease for this group of patients [4]. Thus, it is important for paediatricians to remember that psoriasis may be a complication of an infection. Furthermore, studies showed a correlation between exacerbation of psoriatic symptoms and mental suffering [3]. Given that every person is subject to an increasing number of stress factors and continual peer pressure from an early age, psoriasis appears to be a common problem that every GP has to deal with.
Zestawiając czynniki wywołujące łuszczycę w badanej grupie (tab. 1), stwierdzono, że największy wpływ mają stres oraz infekcje - 29 (91\%) osób, w znacznie mniejszym stopniu urazy mechaniczne i operacje $-3(9 \%)$.

Superantygeny bakteryjne i wirusowe w wyniku pobudzenia receptora skórnego limfocytów mogą wpływać na mechanizm migracji limfocytów T z włośniczek do naskórka, czego skutkiem jest indukcja procesu zapalnego. Wysiewy łuszczycy często są spowodowane zakażeniem różnymi drobnoustrojami, przede wszystkim paciorkowcami i gronkowcami [2, 3]. Dlatego wydaje się, że pacjentów z licznymi, nawracającymi infekcjami należy objąć szczególną opieką, gdyż są oni w większym stopniu zagrożeni wystąpieniem łuszczycy. Grupą bardzo podatną na infekcje są dzieci i młodzież w wieku szkolnym, u których obserwuje się częste infekcje na tle bakteryjnym lub przebiegające $\mathrm{z}$ nadkażeniem bakteryjnym. Jedną z typowych chorób dla tej grupy pacjentów jest paciorkowcowe zapalenie gardła i migdałków podniebiennych [4]. Dlatego ważne jest, aby pediatrzy pamiętali, że łuszczyca może stanowić powikłanie infekcji. Ponadto w badaniach wykazano zależność między nasileniem objawów łuszczycy a zaburzeniami psychicznymi [3]. Ze względu na wzrastające narażenie na coraz liczniejsze czynniki wywołujące stres oraz ciągłą presję otoczenia już od najmłodszych lat - łuszczyca stanowi 
In case of familial clustering, the majority of patients do not show a connection between incidence of psoriasis and familial correlation - 22 (69\%) individuals. Six $(19 \%)$ individuals indicated psoriasis in their parents, 2 (6\%) in distant family, and $1(3 \%)$ in grandparents or siblings respectively. Therefore, during the treatment process it is essential for GPs to take thorough history, build mutual trust, and in cases when a given GP takes care of more than one member of a given family consider other family members even when only one of them is being diagnosed. Psoriasis in an autoimmune disease and in some families it may be inherited as an autosomal dominant disorder with high penetrance, especially loci at chromosome $17 q 25$ and $4 q$ are susceptible. In case of at least a susceptibility site at chromosome 17q25, development of psoriasis does not require HLA-Cw6 presence, and thus, the factor may be considered important [5].

According to the obtained data, patients may be divided into white-collar workers - 7 (22\%), blue-collar workers - 11 (34\%), and pensioners/annuitants/ the unemployed - 14 (44\%). Thereby, psoriasis is not limited exclusively to one professional group. The reason behind it might be that stress, one of the most common triggers of psoriasis, pertains to all people. Average age of patients indicates that they are individuals at the childbearing age; however, the connection between professional activity and incidence of psoriasis is difficult to verify.

Studies confirm that unemployment is a consequence of the disease in employed and professionally active patients. Annually, unemployment caused by psoriasis occurs in $10 \%$ of patients. Many patients are made redundant due to frequent absences and an inability to perform their professional duties right, what obstructs their way for promotion, and results in noticeable obstacles associated with the disease with regard to promotion [6].

An influence of stimulants on psoriasis was the last analysed factor. Among the patients, 15 (17\%) confirmed that they drink alcohol, 6 (29\%) confessed to smoking cigarettes, and none of the patients said they were taking drugs. It was observed that alcohol consumption that may be harmful occurred more often in individuals with severe psoriasis. The problem is more common in male patients than in women. Moreover, alcohol consumption decreases the efficacy and increases the toxicity of systemic anti-inflammatory drugs. Additionally, excessive alcohol consumption impairs the immune system, what in turn leads to an increased risk for infections, and may induce pro-inflammatory production of cytokines, while increasing lymphocyte proliferation and their activation. Therefore, considering an important role played by both GPs and paediatricians, they should remember about shaping good habits in patients and powszechny problem, z którym ma do czynienia każdy lekarz rodzinny.

U większości pacjentów nie stwierdzono rodzinnego występowania choroby - 22 osoby (69\%). Sześć osób (19\%) zgłosiło występowanie łuszczycy u rodziców, 2 osoby (6\%) w dalszej rodzinie, po 1 osobie (3\%) u dziadków lub rodzeństwa. Dlatego lekarz pierwszego kontaktu powinien zadbać o zebranie dokładnego wywiadu, budowanie wzajemnego zaufania, a w trakcie diagnozowania pacjenta powinien uwzględniać członków jego rodzinny, jeśli ma ich pod swoją opieką. Łuszczyca, która jest chorobą autoimmunologiczną, w niektórych rodzinach dziedziczona jest jako cecha autosomalna dominująca z wysoką penetracją. Szczególnie podatne jest loci na chromosomie 17q25 i 4q. W przypadku co najmniej miejsca podatności na chromosomie 17q25, rozwój łuszczycy nie wymaga obecności HLA-Cw6, dlatego czynnik ten można uznać za istotny [5].

Na podstawie danych dotyczących aktywności zawodowej uzyskanych od pacjentów w badanej grupie można wyróżnić: pracowników umysłowych $7(22 \%)$, pracowników fizycznych - 11 (34\%) oraz emerytów, rencistów i osoby bezrobotne - 14 (44\%). Łuszczyca nie jest więc ograniczona wyłącznie do jednej grupy zawodowej. Może to wynikać z faktu, że stres, który jest jednym z najczęstszych inicjatorów łuszczycy, dotyczy każdego. Średnia wieku pacjentów wskazuje, że są to osoby w wieku produkcyjnym, jednak związek między aktywnością zawodową a wystąpieniem choroby jest trudny do stwierdzenia.

Wyniki badań potwierdzają, że skutkiem choroby wśród aktywnych zawodowo pacjentów jest utrata pracy. Rocznie utrata pracy spowodowana łuszczycą występuje u 10\% chorych. Choroba jest przyczyną częstych nieobecności i niezdolności do prawidłowego wykonywania obowiązków służbowych, czego skutkiem są utrudnienia lub brak możliwości awansu, a wielu chorych zostaje zwolnionych z pracy $\mathrm{z}$ tego powodu [6].

Ostatnim analizowanym czynnikiem był wpływ używek na wystąpienie łuszczycy. W badanej grupie $15(71 \%)$ chorych potwierdziło spożywanie alkoholu, 6 (29\%) palenie papierosów, żadna z osób nie przyjmowała narkotyków. Zaobserwowano, że spożywanie alkoholu w sposób, który może być szkodliwy dla zdrowia, jest znacznie częstsze u osób z ciężką łuszczycą. Problem ten dotyczy w większym stopniu mężczyzn, u kobiet jest mniej powszechny. Spożywanie alkoholu zmniejsza skuteczność ogólnoustrojowych leków przeciwzapalnych i zwiększa ich toksyczność. Ponadto nadmierne spożywanie alkoholu powoduje obniżenie odporności, co skutkuje zwiększonym ryzykiem wystąpienia zakażeń. Może także indukować produkcję cytokin prozapalnych, zwiększać proliferację limfocytów i ich aktywację. Dlatego zarówno 
spread the prophylaxis. Alcohol and one of its metabolites - acetone - induce keratinocyte proliferation and increase the mRNA level of genes characteristic for proliferating keratinocytes, such as integrin 5, cyclin D1, and keratinocyte growth factor receptor $[7,8]$.

In addition, there exists a connection between psoriasis and smoking at present or in the past. Studies suggest that smoking may be an independent risk factor for development of psoriasis [9]. Furthermore, it is emphasised that patients may suffer from a higher risk for metabolic diseases (diabetes), heart diseases (ischaemic heart disease), or an increased level of cholesterol and triglycerides due to their lifestyle, i.e. lack of physical activities, increased alcohol consumption, and smoking [10].

All of the above confirm the fact that psoriasis is not only a dermatological problem, but it is closely connected to diseases and disorders of internal medicine. Thus, it is of key importance to provide these patients with fast diagnostics and interdisciplinary care.

\section{CONFLICT OF INTEREST}

The authors declare no conflict of interest. lekarze rodzinni, jak i pediatrzy powinni prowadzić działania profilaktyczne i zachęcać pacjentów do wypracowania prawidłowych nawyków. Alkohol oraz aceton - jeden z jego metabolitów - indukują proliferację keratynocytów i zwiększają poziom mRNA genów charakterystycznych dla namnażających się keratynocytów, m.in. integryny 5, cykliny D1 oraz receptora czynnika wzrostu keratynocytów [7, 8].

Stwierdzono również związek między łuszczycą a paleniem tytoniu - obecnie oraz w przeszłości. Badania potwierdzają, że palenie jest niezależnym czynnikiem ryzyka rozwoju łuszczycy [9]. Chorzy na łuszczycę mają zwiększone ryzyko wystąpienia chorób metabolicznych (cukrzyca), chorób serca (choroba niedokrwienna serca), podwyższonego stężenia cholesterolu i trójglicerydów, co wiąże się ze stylem życia - brakiem ruchu, zwiększonym spożyciem alkoholu i paleniem papierosów [10].

Podsumowując - łuszczyca nie jest tylko problemem dermatologicznym, ale jest ściśle związana ze schorzeniami lub zaburzeniami internistycznymi. Dlatego ważne jest zapewnienie pacjentom szybkiej diagnostyki i objęcie ich opieką interdyscyplinarną.

\section{KONFLIKT INTERESÓW}

Autorzy nie zgłaszają konfliktu interesów.

\section{References \\ Piśmiennictwo}

1. Lowes M.A., Suárez-Fariñas M., Krueger J.G.: Immunology of psoriasis. Annu Rev Immunol 2014, 32, 227-255.

2. Remröd C., Sjöström K., Svensson Å.: Subjective stress reactivity in psoriasis - a cross sectional study of associated psychological traits. BMC Dermatol 2015, 15, 6.

3. Patel N., Nadkarni A., Cardwell L.A., Vera N., Frey C., Patel N., et al.: Psoriasis, depression, and inflammatory overlap: a review. Am J Clin Dermatol 2017, 18, 613-620.

4. Wasilewska A., Zawadzka-Głos L.: Analiza kliniczna pacjentów z ropniem okołomigdałkowym w materiale Kliniki Otolaryngologii Dziecięcej WUM w 2016 roku. Nowa Pediatria 2017, 1, 3-8.

5. West J., Ogston S., Berg J., Palmer C., Fleming C., Kumar V., et al.: HLA-Cw6-positive patients with psoriasis show improved response to methotrexate treatment. Clin Exp Dermatol 2017, 42, 651-655.

6. Claudepierre P., Lahfa M., Levy P., Barnetche T., Bonnet I., Aubert R., et al.: The impact of psoriasis on professional life: pso PRO, a French national survey. J Eur Acad Dermatol Venereol 2018, 32, 1702-1709.

7. Gonzaga H.F.S., Chaves M.D., Gonzaga L.H.S., Picciani B.L., Jorge M.A., Dias E.P., et al.: Environmental factors in benign migratory glossitis and psoriasis: retrospective study of the association of emotional stress and alcohol and tobacco consumption with benign migratory glossitis and cutaneous psoriasis. J Eur Acad Dermatol Venereol 2015, 29, 533-536.

8. Farkas Á., Kemény L.: Psoriasis and alcohol: is cutaneous ethanol one of the missing links? Br J Dermatol 2010, $162,711-716$.

9. Armstron A.W., Harskamp C.T., Dhillon J.S., Armstrong E.J.: Psoriasis and smoking: a systematic review and meta-analysis. Br J Dermatol 2014, 170, 304-314.

10. Itani S., Arabi A., Harb D., Hamzeh D., Kibbi A.G.: High prevalence of metabolic syndrome in patients with psoriasis in Lebanon: a prospective study. Int J Dermatol 2016, 55, 390-395.

Received: 23.02.2019

Accepted: 31.03 .2019

Otrzymano: 23.02.2019 r.

Zaakceptowano: 31.03.2019 r.

\section{How to cite this article}

Grabarek B.O., Michalska-Bańkowska A., Wcisło-Dziadecka D.L.: Analysis of factors predisposing to the occurrence of psoriasis among patients qualified for cyclosporine A therapy - a pilot study. Dermatol Rev/Przegl Dermatol 2019, 106, 225-228. DOI: https://doi.org/10.5114/dr.2019.85581. 